\title{
Correction to: Divergence in chondrogenic potential between in vitro and in vivo of adipose- and synovial-stem cells from mouse and human
}

Ryota Chijimatsu1*, Satoshi Miwa², Gensuke Okamura ${ }^{3}$, Junya Miyahara², Naohiro Tachibana², Hisatoshi Ishikura², Junya Higuchi ${ }^{2}$, Yuji Maenohara ${ }^{2}$, Shinsaku Tsuji ${ }^{4}$, Shin Sameshima ${ }^{2}$, Kentaro Takagi², Keiu Nakazato ${ }^{2}$, Kohei Kawaguchi ${ }^{2}$, Ryota Yamagami ${ }^{2}$, Hiroshi Inui ${ }^{2}$, Shuji Taketomi ${ }^{2}$, Sakae Tanaka ${ }^{2}$ and Taku Saito ${ }^{2}$

Correction to: Stem Cell Research \& Therapy (2021) 12:405 https://doi.org/10.1186/s13287-021-02485-5

The original article [1] contained errors in the presentation of the authors' names where by almost all authors' names were mistakenly inverted.

This has since been corrected, and all authors' names are now displayed appropriately.

\section{Author details}

${ }^{1}$ Bone and Cartilage Regenerative Medicine, Graduate School of Medicine, The University of Tokyo, Tokyo, Japan. ${ }^{2}$ Sensory and Motor System Medicine, Graduate School of Medicine, The University of Tokyo, Tokyo, Japan. ${ }^{3}$ Orthopaedic Surgery, Osaka Rosai Hospital, Osaka, Japan. ${ }^{4}$ Avenue CellClinic, Tokyo, Japan.

Published online: 26 August 2021

\section{Reference}

1. Chijimatsu R, et al. Divergence in chondrogenic potential between in vitro and in vivo of adipose- and synovial-stem cells from mouse and human. Stem Cell Res Ther. 2021;12:405. https://doi.org/10.1186/ s13287-021-02485-5.

\section{Publisher's Note}

Springer Nature remains neutral with regard to jurisdictional claims in published maps and institutional affiliations. permits use, sharing, adaptation, distribution and reproduction in any medium or format, as long as you give appropriate credit to the original author(s) and the source, provide a link to the Creative Commons licence, and indicate if changes were made. The images or other third party material in this article are included in the article's Creative Commons licence, unless indicated otherwise in a credit line to the material. If material is not included in the article's Creative Commons licence and your intended use is not permitted by statutory regulation or exceeds the permitted use, you will need to obtain permission directly from the copyright holder. To view a copy of this licence, visit http://creativecommons.org/licenses/by/4.0/. The Creative Commons Public Domain Dedication waiver (http://creativecommons.org/publicdomain/zero/1.0/) applies to the data made available in this article, unless otherwise stated in a credit line to the data. 